\title{
Growing Public Health Concerns from Poor Urban Air Quality: Strategies for Sustainable Urban Living
}

\author{
Bhaskar Kura, Suruchi Verma, Elena Ajdari, Amrita Iyer \\ Civil \& Environmental Engineering, University of New Orleans, Louisiana, U.S.A \\ Email: bkura@uno.edu
}

Received 2013

\begin{abstract}
Urban areas around the world, particularly in emerging nations such as China, India, and Brazil are experiencing high levels of air pollution due to increased population, economy, spending, and consumption, all of which contribute to deterioration in environmental and public health conditions in urban areas. This paper briefly discusses important sources of air pollution, air pollutants of concern, public health impacts, and proposed strategies to combat urban air pollution and promote sustainable urban living. A team of researchers under the mentorship of the main author is working on a number of air quality projects that involve air quality monitoring (sources, ambient, indoor, and occupational), emissions modeling, atmospheric dispersion modeling, air pollution control, and development of knowledge-based systems to manage air quality. This paper presents potential strategies that could help address the growing public health concerns in urban areas and promote sustainable and healthy living.
\end{abstract}

Keywords: Urban Air Quality; Exposures to Air Pollutants; Risk Assessment; Public Health

\section{Introduction}

The populations of the rapidly expanding cities of Asia, Africa, and Latin America are increasingly exposed to ambient air pollutants by several folds compared to the levels of exposures in developed countries. It is estimated that more than 1 billion people are exposed to outdoor air pollution annually. Urban air pollution is linked to about 1 million premature deaths and 1 million pre-native deaths each year [1]. Urban air pollution is estimated to cost approximately $2 \%$ of GDP in developed countries and $5 \%$ in developing countries [1]. Rapid urbanization has resulted in increasing urban air pollution in major cities, especially in developing countries.

The potential for serious consequences of exposure to high levels of ambient air pollution was made clear in the mid-20th century when cities in Europe and the United States experienced episodes of air pollution, such as the incidents of London Fog of 1952 [2] and Donora Smog of 1948 [3], which resulted in large numbers of excess deaths and hospital admissions. In more recent years, the "gray sky" phenomenon has been the subject of growing public concern. Research shows that high levels of ambient fine particles $\left(\mathrm{PM}_{2.5}\right)$ lead to poor visibility [4].

Urban air pollution occurs when there are continuous or large emissions of air pollutants. The level of pollution depends on the meteorological (wind conditions and atmospheric stability) conditions as well. Urban air pollution is usually associated with high quantities of sulfur dioxide, oxides of carbon (dioxide and monoxide), oxides of nitrogen, and particulate matter $\left(\mathrm{PM}_{10}\right.$ and $\left.\mathrm{PM}_{2.5}\right)$ present in the atmosphere. Depending on other emission sources in cities, heavy metals and volatile organic compounds (VOCs) are also present. In the United States air pollutants are broadly categorized into criteria pollutants $\left(\mathrm{SO}_{2}, \mathrm{NO}_{\mathrm{x}}, \mathrm{CO}, \mathrm{O}_{3}, \mathrm{PM}_{10}\right.$ and $\left.\mathrm{Pb}\right)$ and hazardous air pollutants (HAPs). Criteria pollutants have federal standards as promulgated by the United States Environmental Protection Agency (U.S. EPA) which are shown in Table 1. Whereas HAPs do not have national ambient standards and the goal is to eliminate them from the air environment to the extent possible as they are considered to be hazardous/toxic to human health at any levels.

Data from the World Health Organization (WHO) indicates that the world's average $\mathrm{PM}_{10}$ levels by region ranges from 21 to $142 \mu \mathrm{g} / \mathrm{m}^{3}$, with a world average of 71 $\mu \mathrm{g} / \mathrm{m}^{3}[5]$. Scientific studies suggest that fine particulate matter - less than 10 microns in diameter $\left(\mathrm{PM}_{10}\right)$ - is likely to be the most dangerous because such fine particles can be inhaled deeply into the lungs where the clearance time of deposited particles is much longer, increasing the potential for adverse health effects.

Countries like China, India and Pakistan have recently become highly polluted in terms of air pollution. By the end of 2011, the mainland of the People's Republic of China had a total urban population of 691 million or $51.2 \%$ of the total population, rising from $26 \%$ in 1990 . 
In the 11-yr period of $1990-2001$, the urban population increased $10 \%$, from $26 \%$ to $36 \%$ of the population as seen in Figure 1. Similarly, GDP changes are shown in Figure 2[6].

Table 1. National ambient air quality standards (NAAQs) for criteria pollutants [Adapted from 17].

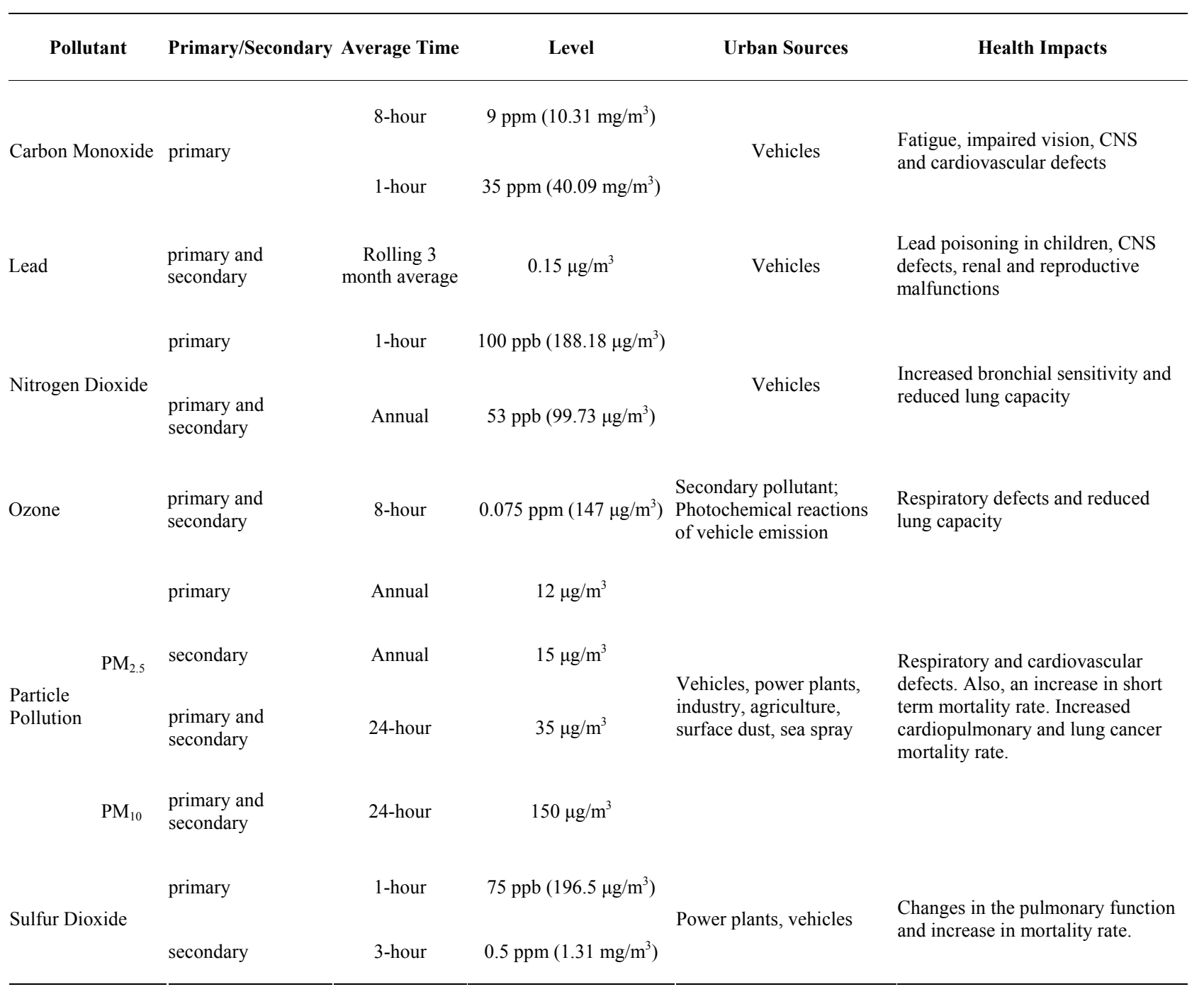

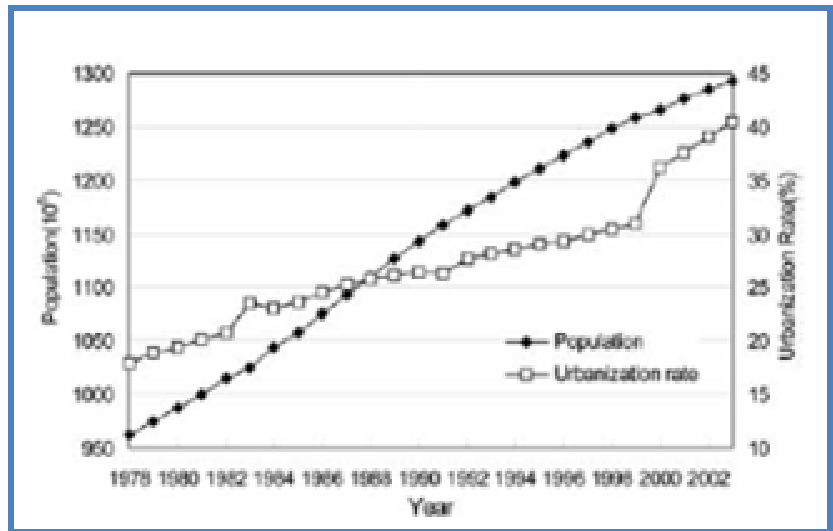

(a)

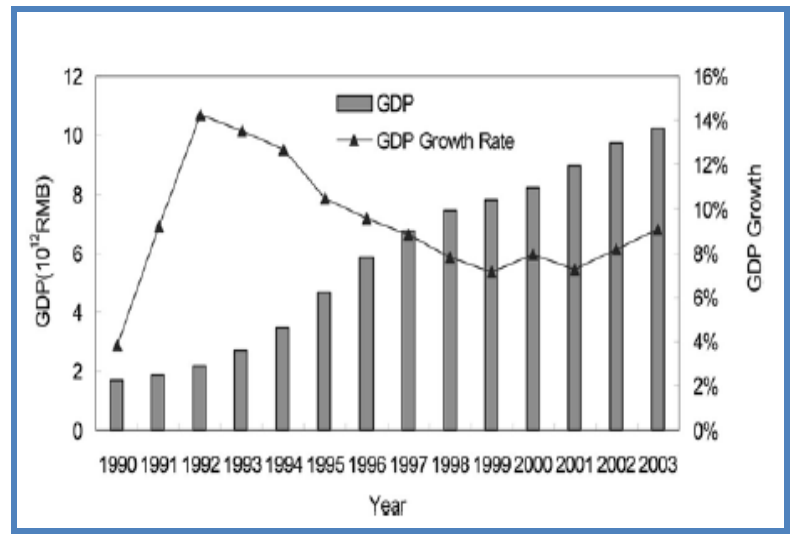

(b)

Figure 1. (a) Population and urbanization rate increase in China and (b) Gross domestic product growth in China from 1990 to $2003[6]$. 


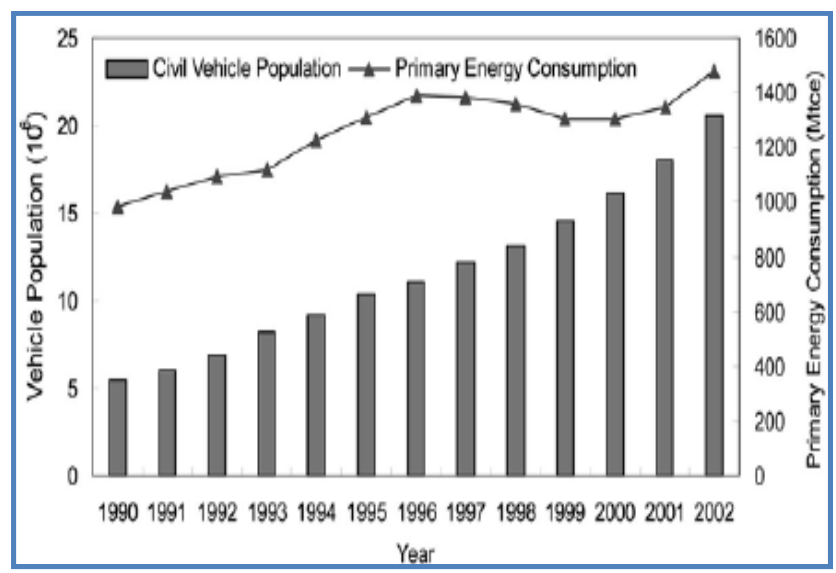

(a)

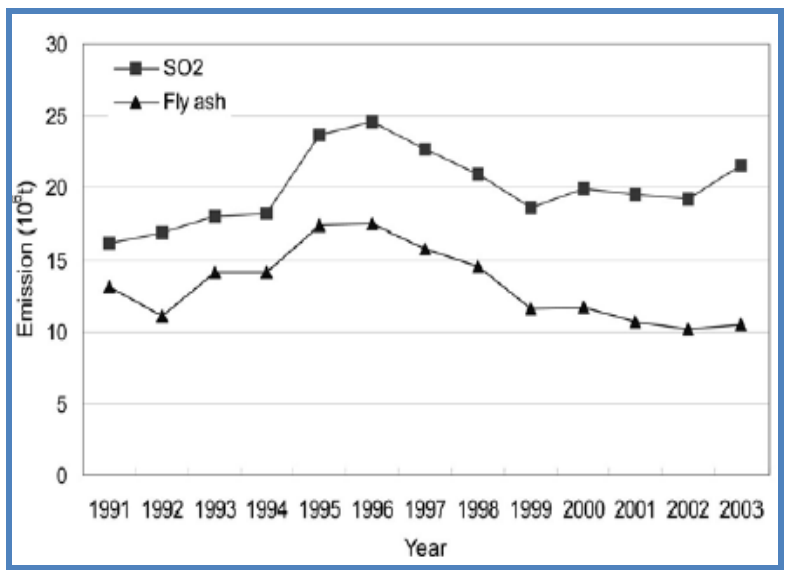

(b)

Figure 2. (a) Energy consumption and vehicle population growth in China and (b) SO2 and fly ash emission in China [6].

More than 450 million of China's 1.3 billion people are now living in urban areas where over 70 percent of China's gross domestic product (GDP) is generated [7]. Two out of three cities in China failed to meet the residential ambient air quality standard, resulting in large population exposure to health risks such as chronic bronchitis, pulmonary heart disease, and lung cancer. Respiratory diseases are a leading cause of premature deaths in China. In the long term, China faces increasing urbanization; according to predictions, nearly $70 \%$ of the population will live in urban areas by 2035[8].

In addition to $\mathrm{PM}_{10}$ and $\mathrm{PM}_{2.5}$, China has large emissions of sulfur dioxide and total suspended particles (TSP) [9]. In 2001, the concentration of $\mathrm{PM}_{2.5}$ in Beijing averaged $110 \mu \mathrm{g} / \mathrm{m}^{3}$, more than seven times the ambient air quality standard established for the United States by the U.S. EPA for fine particulate matter [10].

According to the 2001-2008 "State of the Environment in China" reports, the average daily concentration of $\mathrm{SO}_{2}$ in urban air was between $1-389 \mu \mathrm{g} / \mathrm{m}^{3}$ while the average daily $\mathrm{NO}_{2}$ urban air concentration in China fluctuated between 2 and $77 \mu \mathrm{g} / \mathrm{m}^{3}$. At present, the particulate pollution in China's ambient air is very serious, with not only high levels of TSP concentrations but also comparatively high levels of $\mathrm{PM}_{10}$ and $\mathrm{PM}_{2.5}$ concentrations [11].

Figures 3-5 depict the ambient air quality in some of the cities of China [9].

In addition to air pollution, water pollution and other forms of pollution also pose serious threat to human health. Clean water is very essential for consumption by an individual. However, in most of the developing cities (or countries), clean water is readily available via water treatment plants set up by various governmental and nongovernmental agencies. Air pollution is one thing that can only be treated at the source of the pollution. Once the pollutant is emitted into the atmosphere, it is very difficult to clean up.

\section{Sources of Urban Air Pollution}

Several sources were identified that cause urban air pollution. The major source of deterioration of urban air quality is transportation. Vehicles like cars or trucks run on internal combustion engines which use gasoline or other fossil fuels. This process of burning the fuel to power vehicles contributes to air pollution by releasing air pollutants such as particulates (TPM, $\mathrm{PM}_{10}, \mathrm{PM}_{2.5}$ ), $\mathrm{SO}_{2}, \mathrm{NO}_{\mathrm{x}}, \mathrm{CO}$, and unburned hydrocarbons. These emissions cause cancer and other serious health issues.

The American Lung Association reports that 30,000 people are killed by car emissions annually in the United States alone [12]. A study by the World Health Organization reported in National Geographic News states that air pollution in China is related to around 656,000 deaths every year throughout the country [13]. China currently has one car for every 17.2 people. In the United States, there's one car for every 1.3 people. If China were to catch up with the U.S. car ownership rate, the country would field a billion vehicles all by itself [14].

Listed below are the specific air pollutants emitted from transportation related sources. Percentages mentioned indicate contribution of these transportation sources to the overall ambient concentration of that particular air pollutant.

- Carbon monoxide (CO) [70\% to $90 \%]$

- Hydrocarbons likemethane $\left(\mathrm{CH}_{4}\right)$, gasoline $\left(\mathrm{C}_{8} \mathrm{H}_{18}\right)$ and diesel vapors, benzene $\left(\mathrm{C}_{6} \mathrm{H}_{6}\right)$, formaldehyde $\left(\mathrm{CH}_{2} \mathrm{O}\right)$, butadiene $\left(\mathrm{C}_{4} \mathrm{H}_{6}\right)$ and acetaldehyde $\left(\mathrm{CH}_{3} \mathrm{CHO}\right)$. [50\%]

- Oxides of nitrogen $\left(\mathbf{N O}_{\mathbf{x}}\right)$ - [45\% to $\left.50 \%\right]$

- Greenhouse gases like carbon dioxide [30\%] in developed countries and [15\%] worldwide. China emits 6,018 million ton of greenhouse gases each year.

- Particulate matter $\left(\mathbf{P M}_{10} / \mathbf{P M}_{2.5}\right)$ - $[25 \%]$. In the United States particulate matter $\left(\mathrm{PM}_{10}\right)$ levels above 50 micrograms are considered unsafe. In Europe, the average levels for $\mathrm{PM}_{10}$ is approximately $40 \mu \mathrm{g} / \mathrm{m}^{3}$, and in Beijing the average level is $141 \mu \mathrm{g} / \mathrm{m}^{3}$. 
- Sulfur dioxide $\left(\mathrm{SO}_{2}\right)$ - [5\%]

- Lead- Lead is a toxic metal mainly used as an antiknocking agent in gasoline (Lead tetraethyl $\left.-\mathrm{Pb}\left(\mathrm{C}_{2} \mathrm{H}_{5}\right)_{4}\right)$ and is also used in batteries (lead dioxide as an anode and lead as a cathode).

- Odors- Diesel and gasoline engines are the major sources of odors. [15]

Gas stations also contribute to urban air pollution, particularly because of the evaporation of gasoline during filling of gas station storage tanks and vehicles. The main compounds are: benzene, toluene, ethylbenzene, xylenes, lead, methyl tertiary butyl ether (MTBE; MTBE is currently classified as a potential human carcinogen), ethylene dichloride (EDC) and naphthalene. [16] Dry cleaning shops are common sources present in the urban environment which pose significant threat to human health. These facilities emit volatile organic compounds (VOC), most of which are considered to be HAPs. Dry cleaning units emit perchloroethylene (Perc) and petroleum solvents[18]. Perc may cause cancer in human and is identified as HAP. Perchloroethylene can be measured in the breath, and breakdown products of it can be measured in the blood and urine [19]. Petroleum solvents used in this industry also emit HAPs and VOCs. Specific VOCs include: Stoddard solvent which is a mixture of C5-C12 petroleum hydrocarbons containing 30\% - 50\% straight-and branched-chained alkanes, $30 \%-40 \%$ cycloalkanes, and $10 \%$ - 20\% alkyl aromatic compounds[20].Other contaminants are carbon tetrachloride, trichloroethylene,

perchloroethylene, 1,1,2-trichlorotrifluoroethane, 1,1,1-trichloroethane, glycol ethers, decamethylcylcopentasiloxane, n-propyl bromide, pure dry ${ }^{\mathrm{TM}}[20]$.

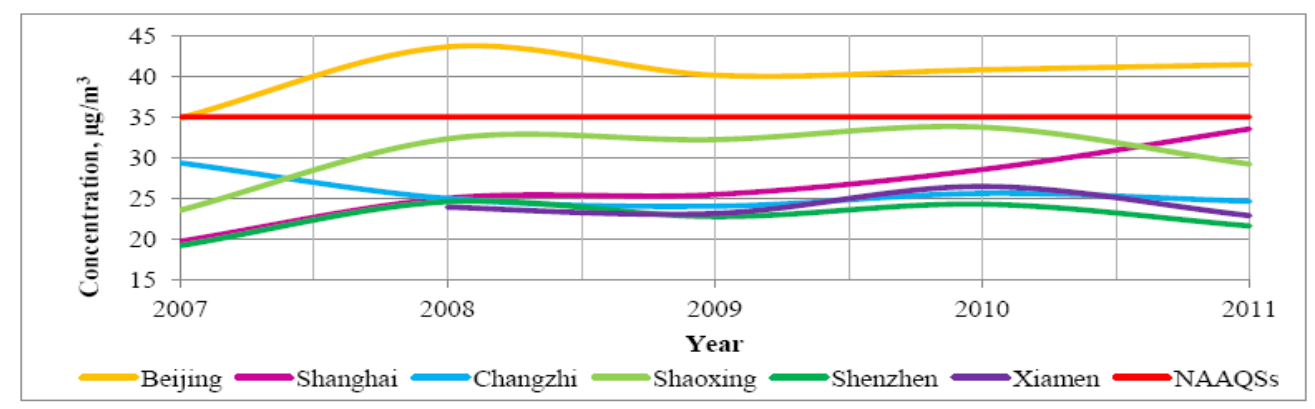

Figure 3. $\mathrm{PM}_{10}$ yearly ambient concentration in some cities of China [9].

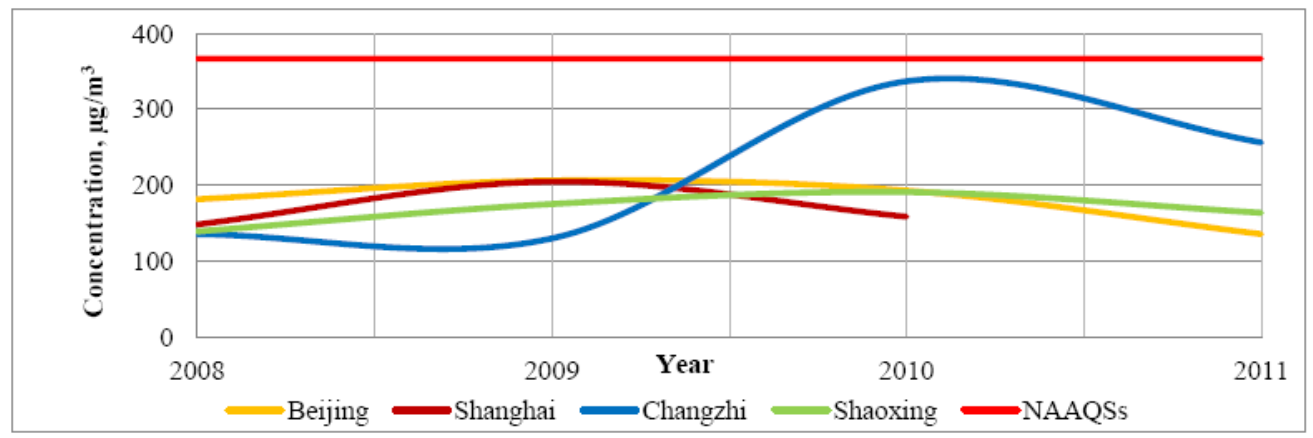

Figure 4. $\mathrm{SO}_{2}$ yearly ambient concentration in some cities of China [9].

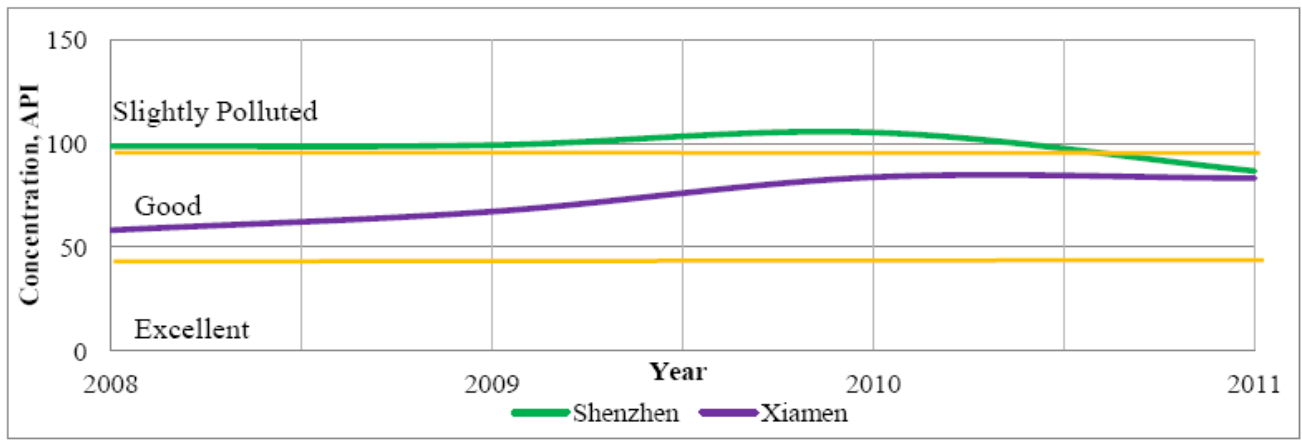

Figure 5. $\mathrm{NO}_{2}$ yearly ambient concentration in some cities of China [9]. 
Compounds in VOCs can react with sunlight and contribute to ground level ozone which can cause respiratory disease. In 1991, California wasthe first state which declared perchloroethylene as a toxic chemical.As a result of thisban will be implemented on using this material by thedry cleaners in that state from 2023 [21]A recent study at Georgetown University shows that perc remains in dry-cleaned clothes and the level of this chemical increases with repeated dry cleanings [22].

\section{Health Impacts from Exposure to Air Pollutants}

The health impacts of a particular air pollutant depends on the pathway that it enters a human body and the type of interactions it goes through once it is inside the body. This is depicted in Figure 6. Usually, the pathway of exposure to an air pollutant is inhalation of the pollutant. Another route of exposure could be dermal where the skin comes in contact with the pollutant. Skin offers a good resistance to any air pollutant, but in case of any cracks or aberrations, it is highly possible that the pollutant might enter the body through the skin.

The extent of exposure depends on the dose that the individual is exposed to and the time that the individual was exposed for. Even when the individual goes through a very small dosage of the pollutant, if the time period of exposure is long enough, the person can suffer a fatality in some cases. Based on this, the health impacts are classified as acute and chronic.

Air pollutants majorly affect the respiratory system that mainly constitutes the lungs. The various effects on the respiratory system are increased respiratory (lung) illnesses, asthma exacerbations (makes asthma worse), decreased lung function in children, and chronic respiratory illnesses. In some cases with high levels of exposure, air pollutants can cause cancer and premature death.

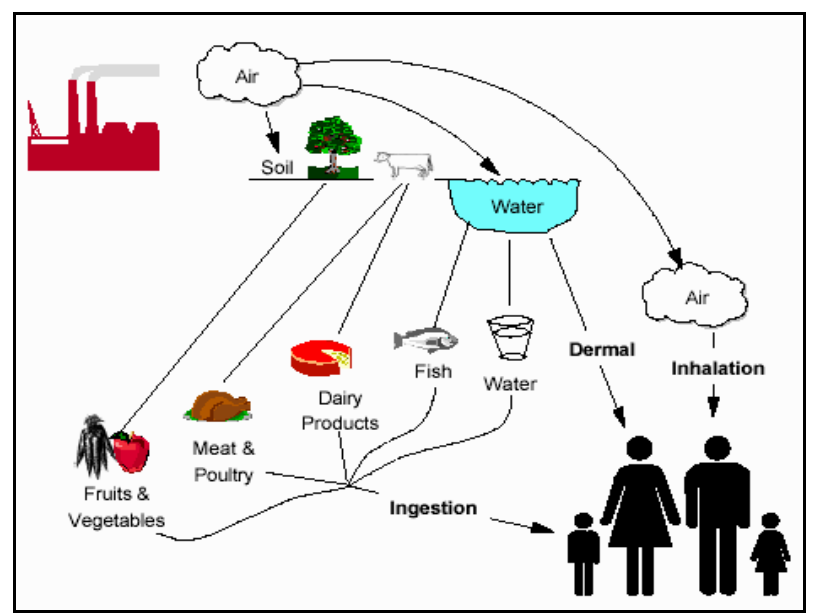

Figure 6. Exposure pathways for air pollutants (Source: EPA).
Once inside the lungs, the air pollutants get picked up by the bloodstream and can cause a number of cardiovascular impacts. These include, but not limited to, myocardial infarction (heart attack), stroke, hypertension (high blood pressure), atherosclerosis (artery disease), arrhythmia (irregular heartbeat), and thrombosis (abnormal clotting).

In several cases, certain reproductive (birth) defects have been observed. These birth defects are preterm babies (born earlier than they should be), low birth weight, slow growth in the womb, miscarriage, still birth, premature birth, infant mortality. Studies have found that a $10 \%$ increase in $\mathrm{PM}$ and $\mathrm{SO}_{2}$ pollution are associated with a $1 \%$ increase in infant deaths. Also, breathing high levels of urban air pollution almost tripled a mother's chances of having a low birth weight baby.

More in-depth health impacts are shown in Tables 1-3.

Quantifying the magnitude of these health impacts in cities worldwide, however, presents considerable challenges owing to the limited availability of information on both effects on health and on exposures to air pollution in many parts of the world. Man-made urban air pollution is a complex mixture with many toxic components.

\section{An Integrated Approach to Risk Assessment}

An air quality research team at the University of New Orleans (UNO) is involved in research that promotes integrated air quality management using health risk as an important criteria. As part of integrated air quality management, the team typically uses the following strategies and research methods to achieve the overall air quality management goals:

- Air quality monitoring: Monitoring of ambient air quality, source emissions, indoor air quality, and occupational exposures are monitored as part of the research methodology.

- Modeling: Modeling strategies used include, emissions modeling, atmospheric dispersion modeling, exposure modeling (both ambient conditions and indoor conditions).

- Clean/green technologies: As part of this initiative, research efforts are made to optimize industrial and municipal processes with the goal of (a) promoting/increasing efficiency, (b) minimize consumption of natural resources, input materials, fuel, and energy, (c) minimize life-cycle costs, (d) reduce waste quantities, and (e) minimize health risks (cancer and non-cancer health risks). UNO has an emissions test facility which can be used to simulate industrial and other processes to evaluate existing manufacturing technologies and recommend process changes to achieve environmental friendliness. 
Table 2. Health Effects of Airborne VOCs.

\begin{tabular}{|c|c|c|c|c|c|c|}
\hline Air Pollutant & $\begin{array}{l}\text { OSHA } \\
\text { PEL } \\
\left(\mu g / \mathbf{m}^{3}\right)\end{array}$ & $\begin{array}{l}\text { NIOSH } \\
\text { REL } \\
\left(\mu g / \mathbf{m}^{3}\right)\end{array}$ & Toxicity/Health Effects & $\begin{array}{l}\text { URE } \\
\left(\mu g / \mathbf{m}^{3}\right)^{-1}\end{array}$ & $\begin{array}{l}\text { RFC } \\
\left(\mathrm{mg} / \mathrm{m}^{3}\right)\end{array}$ & $\begin{array}{l}\text { Urban } \\
\text { Sources }\end{array}$ \\
\hline $\begin{array}{l}\text { 1,1,1-Trichloroetha } \\
\text { ne / Methyl Chlo- } \\
\text { roform }\left(\mathrm{CH}_{3} \mathrm{CCl}_{3}\right)\end{array}$ & $1,900,000$ & $1,900,000$ & $\begin{array}{l}\text { Irritation eyes, skin; headache, lassitude } \\
\text { (weakness, exhaustion), central nervous system } \\
\text { depression, poor equilibrium; dermatitis; cardiac } \\
\text { arrhythmias; liver damage }\end{array}$ & N/A & 5 & $\begin{array}{l}\text { Dry } \\
\text { Cleaning }\end{array}$ \\
\hline $\begin{array}{l}\text { 1,1,2-Trichlorotrifl } \\
\text { uoroethane/CFC- } \\
113\left(\mathrm{CCl}_{2} \mathrm{FCCIF}_{2}\right)\end{array}$ & $7,600,000$ & $7,600,000$ & $\begin{array}{l}\text { Irritation skin, throat, drowsiness, dermatitis; } \\
\text { central nervous system depression; in animals: } \\
\text { cardiac arrhythmias, narcosis }\end{array}$ & N/A & N/A & $\begin{array}{l}\text { Dry } \\
\text { Cleaning }\end{array}$ \\
\hline $\begin{array}{l}\text { 1,3-Butadiene } \\
\left(\mathrm{CH}_{2}=\mathrm{CHCH}=\mathrm{CH}\right)\end{array}$ & 2,200 & A & $\begin{array}{l}\text { Irritation eyes, nose, throat; drowsiness, dizziness; } \\
\text { liquid: frostbite; teratogenic, reproductive effects; } \\
\text { [potential occupational carcinogen] }\end{array}$ & $3.00 \mathrm{E}-05$ & $2.00 \mathrm{E}-03$ & $\begin{array}{l}\text { Traffic; Gas } \\
\text { Stations; }\end{array}$ \\
\hline $\begin{array}{l}\text { Benzene } \\
\left(\mathrm{C}_{6} \mathrm{H}_{6}\right)\end{array}$ & $\mathrm{F}$ & 320 & $\begin{array}{l}\text { Irritation eyes, skin, nose, respiratory system; } \\
\text { dizziness; headache, nausea, staggered gait; ano- } \\
\text { rexia, lassitude (weakness, exhaustion); dermatitis; } \\
\text { bone marrow depression; [potential occupational } \\
\text { carcinogen] }\end{array}$ & 7.80E-06 & $3.00 \mathrm{E}-02$ & $\begin{array}{l}\text { Traffic; Gas } \\
\text { Stations; }\end{array}$ \\
\hline $\begin{array}{l}\text { Carbon tetrachlo- } \\
\text { ride } \\
\left(\mathrm{CCl}_{4}\right)\end{array}$ & 63,000 & 12,600 & $\begin{array}{l}\text { Irritation eyes, skin; central nervous system de- } \\
\text { pression; nausea, vomiting; liver, kidney injury; } \\
\text { drowsiness, dizziness, incoordination; [potential } \\
\text { occupational carcinogen] }\end{array}$ & $6.00 \mathrm{E}-06$ & $1.00 \mathrm{E}-01$ & $\begin{array}{l}\text { Dry } \\
\text { Cleaning }\end{array}$ \\
\hline $\begin{array}{l}\text { Ethylbenzene } \\
\left(\mathrm{CH}_{3} \mathrm{CH}_{2} \mathrm{C}_{6} \mathrm{H}_{5}\right)\end{array}$ & 435,000 & 435,000 & $\begin{array}{l}\text { Irritation eyes, skin, mucous membrane; headache; } \\
\text { dermatitis; narcosis, coma }\end{array}$ & $2.50 \mathrm{E}-06$ & 1 & $\begin{array}{l}\text { Gas } \\
\text { stations }\end{array}$ \\
\hline $\begin{array}{l}\text { Methyl-tert-butyl } \\
\text { ether (MTBE) } \\
\text { ((CH3)3COCH3) }\end{array}$ & N/A & N/A & $\begin{array}{l}\text { Headache, nausea, dizziness, irritation of the nose } \\
\text { or throat, and sense of confusion }\end{array}$ & $2.60 \mathrm{E}-07$ & 3 & $\begin{array}{l}\text { Gas } \\
\text { stations }\end{array}$ \\
\hline $\begin{array}{l}\text { Toluene } \\
\left(\mathrm{C}_{6} \mathrm{H}_{5} \mathrm{CH} \mathrm{H}_{3}\right)\end{array}$ & 760,000 & 375,000 & $\begin{array}{l}\text { Irritation eyes, nose; lassitude (weakness, exhaus- } \\
\text { tion), confusion, euphoria, dizziness, headache; } \\
\text { dilated pupils, lacrimation (discharge of tears); } \\
\text { anxiety, muscle fatigue, insomnia; paresthesia; } \\
\text { dermatitis; liver, kidney damage }\end{array}$ & N/A & 5 & $\begin{array}{l}\text { Gas } \\
\text { stations }\end{array}$ \\
\hline $\begin{array}{l}\text { Formaldehyde } \\
\text { (HCHO) }\end{array}$ & 922.5 & 19.68 & $\begin{array}{l}\text { Irritation eyes, nose, throat, respiratory system; } \\
\text { lacrimation (discharge of tears); cough; wheezing; } \\
\text { [potential occupational carcinogen] }\end{array}$ & $1.30 \mathrm{E}-05$ & $9.80 \mathrm{E}-03$ & Traffic \\
\hline $\begin{array}{l}\text { Acetaldehyde } \\
\left(\mathrm{CH}_{3} \mathrm{CHO}\right)\end{array}$ & 360,000 & N/A & $\begin{array}{l}\text { Irritation eyes, nose, throat; eye, skin burns; der- } \\
\text { matitis; conjunctivitis; cough; central nervous } \\
\text { system depression; delayed pulmonary edema; in } \\
\text { animals: kidney, reproductive, teratogenic effects; } \\
\text { [potential occupational carcinogen] }\end{array}$ & 2.20E-06 & $9.00 \mathrm{E}-03$ & Traffic \\
\hline $\begin{array}{l}\text { o- Xylene } \\
\left(\mathrm{C}_{6} \mathrm{H}_{4}\left(\mathrm{CH}_{3}\right)_{2}\right)\end{array}$ & 435,000 & 435,000 & $\begin{array}{l}\text { Irritation eyes, skin, nose, throat; dizziness, ex- } \\
\text { citement, drowsiness, incoordination, staggering } \\
\text { gait; corneal vacuolization; anorexia, nausea, } \\
\text { vomiting, abdominal pain; dermatitis }\end{array}$ & N/A & $1.00 \mathrm{E}-01$ & Gas stations \\
\hline $\begin{array}{l}\text { p- Xylene } \\
\left(\mathrm{C}_{6} \mathrm{H}_{4}\left(\mathrm{CH}_{3}\right)_{2}\right)\end{array}$ & 435,000 & 435,000 & $\begin{array}{l}\text { Irritation eyes, skin, nose, throat; dizziness, ex- } \\
\text { citement, drowsiness, incoordination, staggering } \\
\text { gait; corneal vacuolization; anorexia, nausea, } \\
\text { vomiting, abdominal pain; dermatitis }\end{array}$ & N/A & $1.00 \mathrm{E}-01$ & Gas stations \\
\hline $\begin{array}{l}\text { m-Xylene } \\
\left(\mathrm{C}_{6} \mathrm{H}_{4}\left(\mathrm{CH}_{3}\right)_{2}\right)\end{array}$ & 435,000 & 435,000 & $\begin{array}{l}\text { Irritation eyes, skin, nose, throat; dizziness, ex- } \\
\text { citement, drowsiness, incoordination, staggering } \\
\text { gait; corneal vacuolization; anorexia, nausea, } \\
\text { vomiting, abdominal pain; dermatitis }\end{array}$ & N/A & $1.00 \mathrm{E}-01$ & Gas stations \\
\hline $\begin{array}{l}\text { Ethylene dichloride } \\
\left(\mathrm{ClCH}_{2} \mathrm{CH}_{2} \mathrm{Cl}\right)\end{array}$ & 202,500 & 4,000 & $\begin{array}{l}\text { Irritation eyes, corneal opacity; central nervous } \\
\text { system depression; nausea, vomiting; dermatitis; } \\
\text { liver, kidney, cardiovascular system damage; } \\
\text { [potential occupational carcinogen] }\end{array}$ & $2.60 \mathrm{E}-05$ & $2.40 \mathrm{E}+00$ & Gas stations \\
\hline $\begin{array}{l}\text { Trichloroethylene } \\
\left(\mathrm{ClCH}=\mathrm{CCl}_{2}\right)\end{array}$ & 537,000 & N/A & $\begin{array}{l}\text { Irritation eyes, skin; headache, visual disturbance, } \\
\text { lassitude (weakness, exhaustion), dizziness, } \\
\text { tremor, drowsiness, nausea, vomiting; dermatitis; } \\
\text { cardiac arrhythmias, paresthesia; liver injury; } \\
\text { [potential occupational carcinogen] }\end{array}$ & $2.00 \mathrm{E}-06$ & $6.00 \mathrm{E}-01$ & $\begin{array}{l}\text { Dry } \\
\text { Cleaning }\end{array}$ \\
\hline $\begin{array}{l}\text { Perchloroethylene } \\
\left(\mathrm{Cl}_{2} \mathbf{C}=\mathrm{CCl}_{2}\right)\end{array}$ & 678,000 & N/A & $\begin{array}{l}\text { Irritation eyes, skin, nose, throat, respiratory sys- } \\
\text { tem; nausea; flush face, neck; dizziness, incoordi- } \\
\text { nation; headache, drowsiness; skin erythema (skin } \\
\text { redness); liver damage; [potential occupational } \\
\text { carcinogen] }\end{array}$ & $5.90 \mathrm{E}-06$ & $2.70 \mathrm{E}-01$ & $\begin{array}{l}\text { Dry } \\
\text { Cleaning }\end{array}$ \\
\hline
\end{tabular}


Table 3. Health effects of airborne metals."

\begin{tabular}{|c|c|c|c|c|c|c|}
\hline $\begin{array}{l}\text { Air } \\
\text { Pollutant }\end{array}$ & $\begin{array}{l}\text { OSHA PEL } \\
\left(\mu \mathrm{g} / \mathrm{m}^{3}\right)\end{array}$ & $\begin{array}{l}\text { NIOSH REL } \\
\left(\mu \mathrm{g} / \mathrm{m}^{3}\right)\end{array}$ & Toxicity/Health Effects & $\begin{array}{l}\mathrm{URE} \\
\left(\mu \mathrm{g} / \mathrm{m}^{3}\right)^{-1}\end{array}$ & $\begin{array}{l}\text { RFC } \\
\left(\mathbf{m g} / \mathbf{m}^{3}\right)\end{array}$ & Urban Sources \\
\hline $\begin{array}{l}\text { Lead } \\
(\mathrm{Pb})\end{array}$ & 50 & 50 & $\begin{array}{l}\text { Lassitude, insomnia; facial pallor; anorexia, } \\
\text { constipation, abdominal pain, colic; anemia; } \\
\text { gingival lead line; tremor; paralysis wrist, } \\
\text { ankles; encephalopathy; kidney disease; irrita- } \\
\text { tion eyes; hypertension }\end{array}$ & $\mathrm{N} / \mathrm{A}^{++}$ & $\begin{array}{l}1.5 \mathrm{E}-04[2 \text { times more } \\
\text { potent that } \mathrm{Hg}]\end{array}$ & $\begin{array}{l}\text { eTraffic-Brake } \\
\text { Dust }\end{array}$ \\
\hline $\begin{array}{l}\text { Antimony } \\
\text { (Sb) }\end{array}$ & 500 & 500 & $\begin{array}{l}\text { Chronic poisoning, functional disorders of the } \\
\text { heart, degeneration of the heart muscle }\end{array}$ & N/A & $\begin{array}{l}2.2 \mathrm{E}-04[1.4 \text { times } \\
\text { more potent that } \mathrm{Hg}]\end{array}$ & $\begin{array}{l}\text { Traffic-Brake } \\
\text { Dust }\end{array}$ \\
\hline $\begin{array}{l}\text { Copper } \\
(\mathrm{Cu})\end{array}$ & 1,000 & 1,000 & $\begin{array}{l}\text { Irritation-Eye, Nose, Throat; Cumulative Lung } \\
\text { Damage } \\
\text { Irritation-Eye, Nose, Throat, Skin---Marked }\end{array}$ & N/A & N/A & $\begin{array}{l}\text { Traffic-Brake } \\
\text { Dust }\end{array}$ \\
\hline $\begin{array}{l}\text { Zinc } \\
(\mathrm{Zn})\end{array}$ & 5,000 & 5,000 & $\begin{array}{l}\text { Respiratory Effects---Acute lung dam- } \\
\text { age/edema Chronic (Cumulative) Toxic- } \\
\text { ity-Suspect Carcinogen or mutagen }\end{array}$ & N/A & N/A & Vehicular tires \\
\hline $\begin{array}{l}\text { Mercury } \\
(\mathrm{Hg})\end{array}$ & 100 & 50 & $\begin{array}{l}\text { Irritation eyes, skin; cough, dyspnea, bronchitis } \\
\text { pneumonitis; tremor, insomnia, lassitude; } \\
\text { stomatitis, salivation; gastrointestinal distur- } \\
\text { bance, anorexia, weight loss; proteinuria }\end{array}$ & N/A & $3.00 \mathrm{E}-04$ & Various \\
\hline $\begin{array}{l}\text { Chromium } \\
(\mathrm{Cr})\end{array}$ & 1,000 & 500 & $\begin{array}{l}\text { Cancer; irritation eyes, skin; lung fibrosis (his- } \\
\text { tologic) }\end{array}$ & $\begin{array}{l}1.2 \mathrm{E}-02[38 \text { times } \\
\text { more carcinogenic } \\
\text { than } \mathrm{Ni}]\end{array}$ & $\begin{array}{l}1 \mathrm{E}-04[3 \text { times more } \\
\text { potent that } \mathrm{Hg}]\end{array}$ & Various \\
\hline $\begin{array}{l}\text { Manga- } \\
\text { nese } \\
(\mathrm{Mn})\end{array}$ & 5,000 & 1,000 & $\begin{array}{l}\text { Asthenia, insomnia, mental confusion; metal } \\
\text { fume fever: dry throat, cough, chest tightness, } \\
\text { dyspnea, rales, flu-like fever; low-back pain; } \\
\text { vomiting; malaise ; lassitude ; kidney damage }\end{array}$ & N/A & $\begin{array}{l}0.5 \mathrm{E}-04[6 \text { times more } \\
\text { potent that } \mathrm{Hg}]\end{array}$ & $e^{\text {Various }}$ \\
\hline $\begin{array}{l}\text { Nickel } \\
(\mathrm{Ni})\end{array}$ & 1,000 & 15 & $\begin{array}{l}\text { Sensitization dermatitis, allergic asthma, pneu- } \\
\text { monitis; [potential occupational carcinogen] }\end{array}$ & $3.12 \mathrm{E}-04$ & $\begin{array}{l}0.9 \mathrm{E}-04[3.3 \text { times } \\
\text { more potent that } \mathrm{Hg}]\end{array}$ & Various \\
\hline $\begin{array}{l}\text { Cadmium } \\
(\mathrm{Cd})\end{array}$ & 5 & N/A & $\begin{array}{l}\text { Pulmonary edema, dyspnea, cough, chest tight- } \\
\text { ness, headache; chills, muscle aches; nausea, } \\
\text { vomiting, diarrhea; anosmia, emphysema, } \\
\text { proteinuria, mild anemia; [potential occupa- } \\
\text { tional carcinogen] }\end{array}$ & $\begin{array}{l}0.18 \mathrm{E}-02[5.8 \text { times } \\
\text { more carcinogenic } \\
\text { than } \mathrm{Ni}]\end{array}$ & $\begin{array}{l}0.1 \mathrm{E}-04[30 \text { times } \\
\text { more potent that } \mathrm{Hg}]\end{array}$ & Various \\
\hline $\begin{array}{l}\text { Arsenic } \\
\text { (As) }\end{array}$ & 10 & 2 & $\begin{array}{l}\text { Ulceration of nasal septum, dermatitis, gastro- } \\
\text { intestinal disturbances, peripheral neuropathy, } \\
\text { hyperpigmentation of skin, [potential occupa- } \\
\text { tional carcinogen] }\end{array}$ & $\begin{array}{l}0.43 \mathrm{E}-02[13.8 \text { times } \\
\text { more carcinogenic } \\
\text { than Ni] }\end{array}$ & $\begin{array}{l}0.15 \mathrm{E}-04[20 \text { times } \\
\text { more potent that } \mathrm{Hg}]\end{array}$ & Various \\
\hline
\end{tabular}

"Note: Ambient Standards for the above air pollutants are not available. Some sources recommend 1/1000th value of OSHA PEL as ambient limit. N/A- Not Available

- Engineering controls: The research team identifies, evaluates, and develops air pollution control technologies appropriate for various industry sectors for both particulates and gaseous air pollutants.

Development of decision support systems: Kura's research team developed a number of decision support systems for industrial environmental management, occupational exposures and health management, health risk management system for public, and life cycle assessment and life cycle costing predictive model for industrial processes.

\section{Proposed Research and Management Strategies for Urban Air Quality Man- agement}

As the urban air environment is contaminated with a variety of pollutants such as criteria pollutants $\left(\mathrm{CO}, \mathrm{SO}_{2}\right.$, $\mathrm{NO}_{\mathrm{x}}, \mathrm{PM}_{10}, \mathrm{PM}_{2.5}, \mathrm{~Pb}, \mathrm{O}_{3}$ ) and hazardous air pollutants (heavy metals, volatile organic compounds, and others) from a wide range of sources such as transportation, com- mercial, and industrial sources, urban air quality management requires a comprehensive and integrate approach. Kura's research team at UNO has significant experience in this area. A conceptual urban air quality management approach is described in this section:

- Identify sources of air pollution in the immediate urban area and the area of influence

- Knowing the sources of air pollution to identify the specific pollutants that may be released in the air environment

- Conduct preliminary air quality monitoring to identify the concentration ranges for air pollutants of concern

- Identify the best monitoringtechniques, equipment, and resources needed to understand the short term and long term trends of these pollutants

- Establish a permanent network of air quality monitoring stations to measure criteria pollutants and hazardous air pollutants

- Develop a database of air pollutant emission quantities from various sources that have been identified for 
the urban area being investigated

- Evaluate the relationships between the emission quantities and the ambient concentrations under various meteorological conditions

- Prioritizethe sources of air pollution for regulating as appropriate

- Use the data obtained from the network of air quality monitoring stations for developing policies to control emissions and also to make changes in public behavior which may be responsible for poor air quality (traffic; open burning; fuel combustion; others)

- Develop a decision support system to integrate the ambient air quality data to compute exposures and health risk probabilities (cancer and non-cancer)

- Use the data from the decision support system to assist the policy makers, scientists, and the public to achieve the required air quality management goals.

A proposed integrated air quality management plan for urban areas is illustrated in Figure 7.

\section{Summary and Conclusions}

This paper presents various urban air quality challenges experienced by many cities around the world. More specifically, types of sources present in urban areas, types of air pollutants, and health hazards associated with most common urban air pollutants. Due to the high concentration of population, recent growth in the economy and increased consumption resulted in deteriorated air quality. Information provided in this paper and some suggested strategies discussed should be helpful to initiate a dialogue among interested parties. While it is not practically feasible to discuss all aspects of integrated urban air quality management strategies, this paper should serve well in undertaking further actions by the stake-holders from the governmental agencies, the scientific community, and the public.

\section{Acknowledgements}

Principal author (who serves on the Board of Trustees of ITU) acknowledges and thanks the financial support received from the International Technological University (ITU), San Jose, CA towards conference travel.

\section{REFERENCES}

[1] Urban Air Quality. United Nations Environment Programme, Urban Environment Unit http://www.unep.org/urban_environment/issues/urban_air .asp

[2] Stegeman, John J. \& Solow, Andrew R, “A Look Back at the London Smog of 1952 and the Half Century Since A Half Century Later: Recollections of the London Fog," Environmental Health Perspectives, 2002.
[3] "Overview of the 1948 Donora Smog," Pennsylvania Department of Environmental Protection.

[4] Y.L. Sun, G.S. Zhuang, Y. Wang, L.H. Han, J.H. Guo, M. Dan, W.J. Zhang, Z.F.Wang and Z.P. Hao, "The Air-Borne Particulate Pollution in Beijing-Concentration, Composition, Distribution and Sources," 2004.

[5] Annual mean PM10 (Particulate matter with diameter of $10 \mu \mathrm{m}$ or less), by city. World Health organization http://www.who.int/phe/health_topics/outdoorair/databas es/en/index.html

[6] J.M. Hao and L.T. Wang, "Improving Urban Air Quality in China: Beijing Case Study," 2005.

[7] Juan, S., "Census: Population hits 1.37b," China Daily, 2011.

http://europe.chinadaily.com.cn/china/2011-04/29/content _12418282.htm

[8] Urban and Rural Areas 2011, United Nations, Department of economic and Social Affairs. http://esa.un.org/unup/Wallcharts/urban-rural-areas.pdf

[9] C. Blazo, B. Kura and N. Halageri, "China: The Fastest Growing Economy and the Associated Air Quality Challenges", Automatic Welding Machinery Association, 2012.

[10] J.L.Wang, Y.H. Zhang, M. Shao, et al. "The Chemical Composition and Quantitative Relationship between Meteorological Condition and Fine Particles in Beijing," Jounal of Environmental Sciences, Vol. 16, 2004, pp. 860-864

[11] Air Quality Information Transparency Index, Institute of Public \& Environmental Affairs http://www.ipe.org.cn/upload/report-aqti-en.pdf

[12] Jacob, S., "Facts of Car Pollution", 2010. http://www.livestrong.com/article/156537-facts-of-car-po llution/

[13] National Geographic News: http://news.nationalgeographic.com/news/2007/07/07070 9-china-pollution.html

[14] Plumer, B., "Air Pollution now Kills more than High cholesterol," 2012.

http://www.washingtonpost.com/blogs/wonkblog/wp/201 2/12/20/air-pollution-now-kills-more-people-than-high-ch olesterol/

[15] Jean-Paul Rodrigue, "The Geography of Transport Systems," 3rd Edition, 2013

[16] Environmental Pollution Centers

[17] NAAQs for criteria pollutants http://epa.gov/air/criteria.html

[18] EPA-outdoor Air-industry,business, and home: Dry Cleaning Operations - Additional information, available at: http://www.epa.gov/oaqps001/community/details/dryclea ning_addl_info.html\#activity2

[19] EPA-Air Toxics Health Effects Notebook, available at http://www.epa.gov/ttn/atw/hlthef/tet-ethy.html

[20] Chemicals used in drycleaning operations report, Bill Linn, Florida Department of Environmental Protection 
(FDEP), Scott Stupak, North Carolina Superfund Section, provided technical support for database development, January 2002, Revised July 2009

[21] NBC news, available at: http:/www.nbcnews.com/id/ 16816627/ns/us_news-environment/t/calif-air-regulators-
ban-dry-cleaning-chemical/\#.USQcPB0skuA

[22] Prof. Paul Roepe, GeorgetownUniversity, available at: http://www.georgetown.edu/story/dry-cleaning-study.htm 1 